\title{
Employees Providenet Fund with Special Reference To Mando India Automotive, Chennai
}

\author{
J Pavithra, Gowtham ashirvad kumar, Sangeetha. M
}

\begin{abstract}
Representative Provident Fund (EPF) is executed by the Employees Provident Fund Organization (EPFO) of India. An opportune store is made with a reason for giving monetary security and solidness representatives. For the most part one contributes in these assets when one begins as worker, the commitments are made all the time (month to month by and large). Its motivation is to enable representatives to spare a small amount of their pay each month, to be utilized in an occasion that the worker is briefly or never again fit to work or at retirement. The ventures made by various individuals/workers are pooled together and contributed by a trust. A foundation with at least 20 laborers working in any of the 180+ ventures should enlist with EPFO. Ordinarily $12 \%$ of the Basic, DA, and money estimation of sustenance recompenses must be added to the EPF account. EPFO is a statutory body of the Indian Government under Labor and Employment Ministry.
\end{abstract}

Keywords: Representative Provident Fund, Solidness, Employment

\section{INTRODUCTION}

Representative Provident Fund (EPF) is actualized by the Employees Provident Fund Organization (EPFO) of India. A fortunate reserve is made with a reason for giving money related security and soundness workers[1],[3],[5]. By and large one contributes in these assets when one begins as representative, the commitments are made all the time (month to month much of the time). Its motivation is to enable representatives to spare a small amount of their compensation consistently, to be utilized in an occasion that the worker is briefly or never again fit to work or at retirement. The speculations made by various individuals/workers are pooled together and contributed by a trust[2 ],[4],[6]. A foundation with at least 20 laborers working in any of the 180+ businesses should enlist with EPFO. Normally $12 \%$ of the Basic, DA, and money estimation of nourishment stipends must be added to the EPF account. EPFO is astatutorybody of the Indian Government under Labor and Employment Ministry.

Revised Manuscript Received on July 22, 2019

Ms. J Pavithra, Department of MBA, Bharath Institute of Higher Education and Research, Chennai, India

Email: pavithralect@yahoo.com

Gowtham ashirvad kumar, Department of MBA, Bharath Institute of

Higher Education and Research, Chennai, India

Email kgowthamaashirwad123@gmail.com

Sangeetha . M, Department of MBA, Bharath Institute of Higher Education and Research, Chennai, India

Email:sangeethagiri07.sg@gmail.com
It is one of the principle stages of reserve funds in India for about all individuals working in Government, Public or Private area Organizations. This article is about what is Employee Provident Fund (EPF), Employee Pension Scheme (EPS), Employees Deposit Linked Insurance Scheme (EDLIS), how the commitments are determined dependent on essential pay and dearness stipend. What is the EPF loan cost, what amount would one spare in EPF, how one would think about the sum amassed in PF. Gathering the representative detail and sending to EPFO. A fortunate store is made with a reason for giving money related security and strength to older individuals. For the most part one contributes in these assets when one begins as worker, the commitments are made all the time (month to month much of the time). It's motivation is to enable representatives to spare their pay each month. The speculations made by various individuals/workers are pooled together and contributed by a trust. A foundation with at least 20 laborers working in any of the ventures should enroll with EPFO. Ordinarily $12 \%$ of the Basic, DA, and money estimation of nourishment recompenses must be added to the EPF account[7],[ 9], [11].

\section{A. Objectives}

To discover the mindfulness about Employees Provident Fund among the workers in the Mando India Pvt Ltd.

- To learn about the fulfillment level of workers towards EPF in Mando India Pvt Ltd.

- To Analyze the EPF advantages to the workers in Mando India Pvt Ltd.

- To distinguish the age gatherings of respondents in association who inclines toward EPF for Loan and different plans.

- To study the motivation behind business fortunate store in association.

\section{B. Scope}

The extent of the Act can be comprehended from its appropriateness. This Act is connected in the accompanying foundations with the exception of the exclusions contained in Section 16 of the Act. [8],[10],[12]

- The Act applies to each foundation which is an industrial facility occupied with any industry determined in timetable I and in which at least 20 people are utilized.

- Any foundation which utilizes at least 20 people or class of such foundations which the focal Government may, by warning in the Official Gazette indicate for this benefit.

- After giving not else than 2 months notice of its expectation

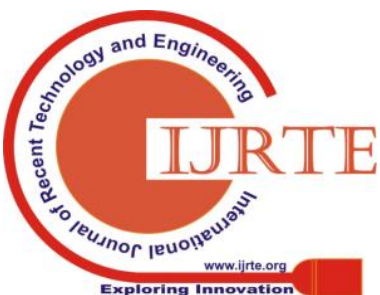


the Central Government apply the arrangements of this Act to any foundation with under 20 people in the work as gave under Section 1(3).

- Notwithstanding anything referenced above as in sub segment (1) of Section 16 (Certain foundation statutorily absolved from the relevance of the Act) where it appears to the Central Provident Fund Commissioner, where as an application made to him for this benefit or something else, that the business and most of workers in connection to any foundation, have concurred that the arrangements of this Act would be made material to the foundation. He may apply the arrangement of this Act to the foundation on and from the date of such understanding or from any resulting date indicated in such understanding under Section 1(4) and Section 3. [13], [15] , [17]

- An foundation to which this Act applies must keep on being administered by this Act, regardless of whether the quantity of people utilized in that falls. so at underneath whenever under area 1(5).

- Under Section 4, the Central Government by a warning in the official Gazette add some other industry to plan I and it will apply to any foundation occupied with such industry.

\section{RESEARCH METHOD}

\section{A. Sampling Plan}

An essential segment of the fresher structure is the examining plan. In particular, it tends to three inquiries;

- Whom to review (test unit)

- How many reviews (the example units)

- How to choose them (the example technique)

Making an enumeration investigation of the entire universe will be incomprehensible on the record of constraints of time. Subsequently examining ends up inescapable. An inspecting is just a part of the absolute worker's quality. As per Yule, A renowned fulfillment, the object of testing is to get most extreme data the parent populace with least exertion straightforward arbitrary inspecting technique has been embraced in this investigation for determination of test size. [14],[16], [18]

\section{B. Sample Size}

The sample size of the study is 30 Employees selected from employees of Redim information systems Pvt Ltd.

\section{Tools Used For Analysing Data}

- Percentage Analysis

- Chi - Square test

- Ranking methord

- T-Test

- Anova test
Table -1 Do you know the benefits of UAN?

\begin{tabular}{|l|l|l|}
\hline $\begin{array}{l}\text { EMPLOYEES } \\
\text { OPINION }\end{array}$ & No. of Respondents & Percentage \\
\hline Yes & 9 & 30 \\
\hline PARTIALY YES & 3 & 10 \\
\hline NO & 12 & 40 \\
\hline PARTIALY NO & 0 & 0 \\
\hline NO IDEA & 6 & 20 \\
\hline TOTAL & 30 & 100 \\
\hline
\end{tabular}

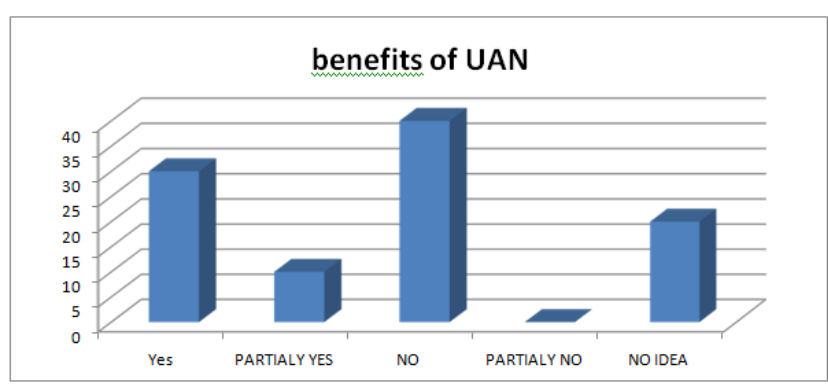

Figure - 1 Do you know the benefits of UAN?

\section{Interpretation:}

$30 \%$ of employees said that they know the benefits of universal account number. And $10 \%$ of peoples they are partially know about the UAN and maximum $40 \%$ of employees says that doesn't know about the UAN and the rest of the $20 \%$ of employees were not have any ideas about the benefits of Universal Account Number.

Table -2

What is the wage/ salary ceiling for EPF coverage prescribed under the Act?

\begin{tabular}{|l|l|l|}
\hline EMPLOYEES OPINION & No. of Respondents & Percentage \\
\hline 6500 & 6 & 20 \\
\hline 15000 & 13 & 43 \\
\hline 20000 & 3 & 10 \\
\hline 25000 & 2 & 7 \\
\hline No Ceiling & 6 & 20 \\
\hline TOTAL & 30 & 100 \\
\hline
\end{tabular}

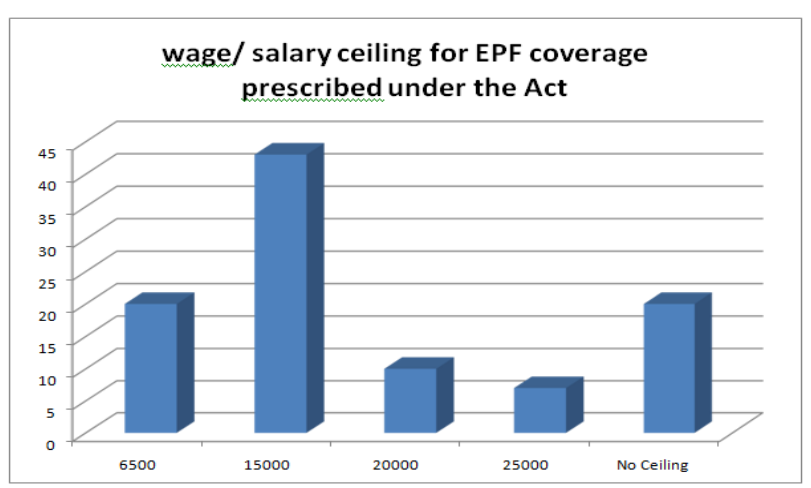

Figure -2 What is the wage/ salary ceiling for EPF coverage

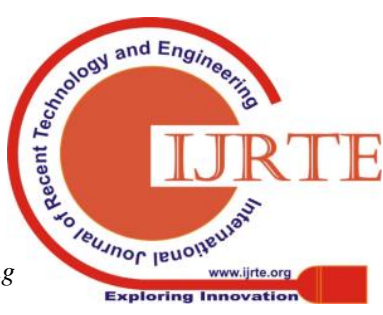


Interpretation -

Only $43 \%$ of peoples were aware of wage ceiling for EPF coverage which is prescribed under the EPF Act. And rest of $37 \%$ of the employees chosen the wrong options.

Table -3

What is the rate of contribution towards employees pension schemes?

\begin{tabular}{|l|l|l|}
\hline EMPLOYEES OPINION & No. of Respondents & PERCENTAGE \\
\hline $10 \%$ & 0 & 0 \\
\hline $8.33 \%$ & 10 & 34 \\
\hline $12 \%$ & 7 & 23 \\
\hline $3.88 \%$ & 0 & 0 \\
\hline NO IDEA & 13 & 43 \\
\hline TOTAL & 30 & 100 \\
\hline
\end{tabular}

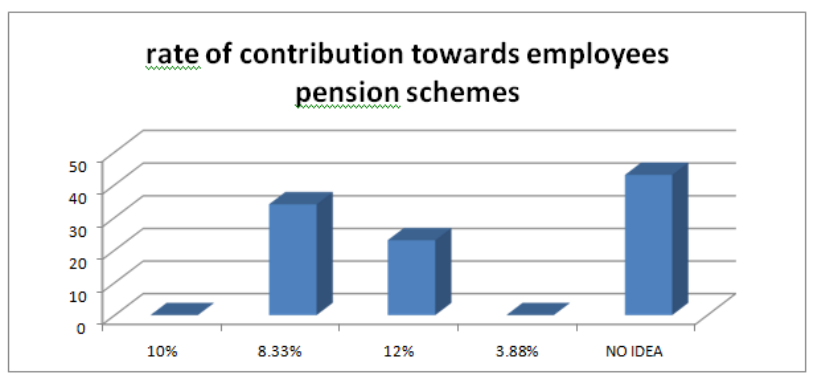

Figure -3 The rate of contribution towards employees pension schemes

\section{Interpretation -}

$43 \%$ of peoples are clear with Insurance schemes have selected the right fund which is $3,60,000$. And some of the employees

Table -4

What is the Maximum benefits under EDLI scheme?

\begin{tabular}{|l|l|l|}
\hline $\begin{array}{l}\text { EMPLOYEES } \\
\text { OPINION }\end{array}$ & No. of Respondents & Percentage \\
\hline 100000 & 0 & 0 \\
\hline 160000 & 8 & 27 \\
\hline 300000 & 3 & 10 \\
\hline 360000 & 13 & 43 \\
\hline NO IDEA & 6 & 20 \\
\hline TOTAL & 30 & 100 \\
\hline
\end{tabular}

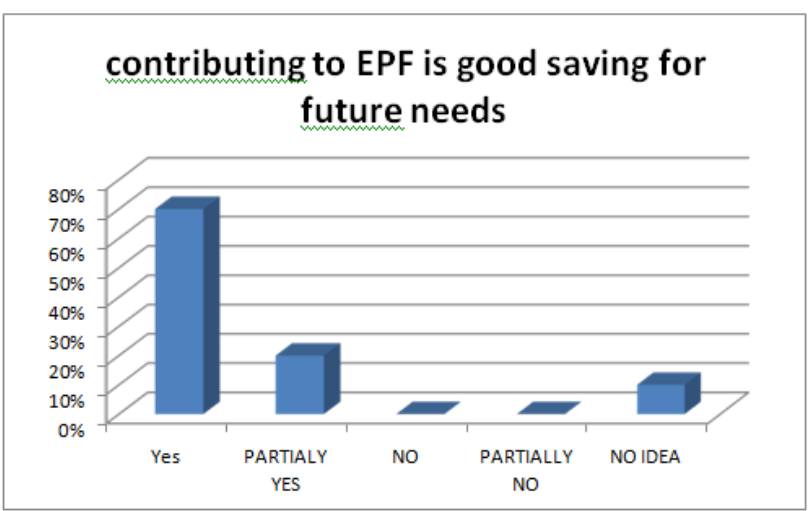

Figure -5 Contributing to EPF is good saving for future needs

\section{Interpretation-}

$70 \%$ of employees said they believe that the EPF is a good savings for their future needs and $20 \%$ of employees were not more aware of EPF savings. $10 \%$ of employees said they have no ideas about it.

Table -6

Do you believe that this is a social security scheme for that employees retirement Life? 


\begin{tabular}{|l|l|l|}
\hline EMPLOYEES OPINION & No. of Respondents & Percentage \\
\hline Yes & 20 & 67 \\
\hline PARTIALY YES & 4 & 13 \\
\hline NO & 0 & 0 \\
\hline PARTIALY NO & 6 & 20 \\
\hline NO IDEA & 0 & 0 \\
\hline TOTAL & 30 & 100 \\
\hline
\end{tabular}

social security scheme for that employees retirement Life

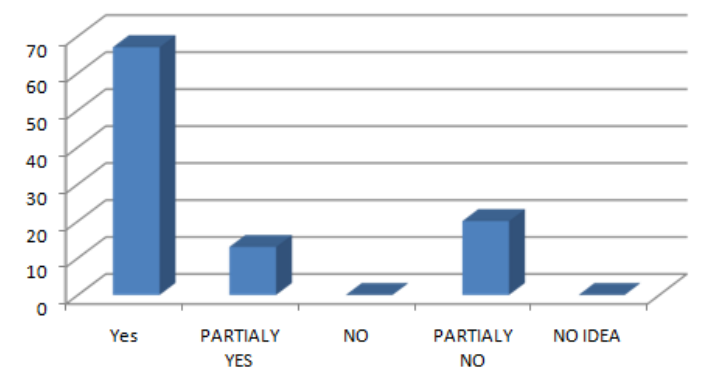

Figure -6 Do you believe that this is a social security scheme for that employees retirement Life

\section{Interpretation:}

$67 \%$ of the respondent believes that it is the social security scheme for that employee retirement life and $20 \%$ are partially no to the social security scheme.

Table -7

Whether your organisation cover all employees under EPF?

\begin{tabular}{|l|l|l|}
\hline EMPLOYEES OPINION & No. of Respondents & Percentage \\
\hline Yes & 26 & 87 \\
\hline PARTIALY YES & 0 & 0 \\
\hline NO & 0 & 0 \\
\hline PARTIALY NO & 0 & 0 \\
\hline NO IDEA & 4 & 13 \\
\hline TOTAL & 30 & 100 \\
\hline
\end{tabular}

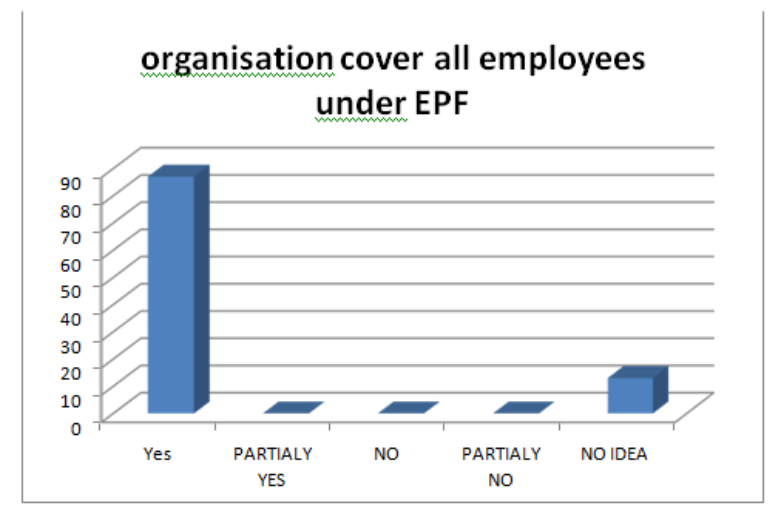

Figure -7

Whether your organisation cover all employees under EPF?

\section{Interpretation:}

$87 \%$ of the respondent said that their organisation cover all employees under EPF.

\section{RESULTS}

$\mathrm{T} \cdot 100 \%$ of workers are clear with the enlistment of organization under representatives opportune store.

- $67 \%$ of representatives are clear with inclusion under the EPF Act.

- $67 \%$ of representatives know about the Employees commitment rate.

- $50 \%$ of representatives know about boss' commitments rates.

- 58\% of individuals acknowledged that their EPF records are kept up in great way by the association.

- $90 \%$ of people groups have mindfulness on assignment of UAN in the association.

- $70 \%$ of individuals opined that the EPF commitments is great investment funds for their future reason.

- $67 \%$ of people groups accept this is a government disability plot for the worker's retirement Life. [26],[28],[30]

- $87 \%$ of people groups educated that their association covers all representatives under the EPF Act.

- The the majority of the senior workers are fulfilled on this EPF plans.

\section{DISCUSSIONS}

$33 \%$ of representatives don't know about the inclusion of EPF in regards to number of representatives working. [31],[33]

- The association ought to illuminate the mindfulness and advantages of government managed savings plans like EPF to its representatives. [19],[21],[23]

- The association should make mindful of its workers with respect to credit/advance accessible under EPF plot.

- $40 \%$ of representatives not mindful about the advantages of Universal Account Number. The association needs to make mindful of such things to workers.

- $67 \%$ of representatives not mindful about the pay roof for EPF inclusion

- 57\% of representatives don't know about max advantages stretched out under EDLI plot.

- $34 \%$ of representatives are disappointed on plan authentication under workers' benefits plot, thus fundamental alteration might be done in the workers' annuity conspire.

\section{V.CONCLUSION}

Workers' fortunate store is significant advantage conspire accessible to every single salaried representative which is kept up by the representatives PF association. [25],[27],[29]

EPF is one of the fundamental sparing stages for reserve funds for all representatives working in government, open or private part association that causes workers to spare a small 
amount of their pay each month that can be utilized in case of unfit to work or upon retirement. [20],[22], [24]

$\mathrm{EPF}$ is one of the most gainful and prominent speculation plans for the salaried individual in India.

EPFO a statutory body under the service of work and business legislature of India administrates this social natural plan.

The EPFO offers numerous online administrations to its entrance to individuals

The administrations are conveyed straightforwardly effectively and serenely to everybody.

\section{REFERENCES}

1) BharthVajan R., Ramachandran S.,Psychographic dimensions of training,2016,International Journal of Pharmacy and Technology,V-8,I-4,P-23727-23729

2) Balakrishnan P., Bharthvajan R.,A study on human resource planning in hospitals in Chennai City,2014,International Journal of Applied Engineering Research,V-9,I-22,P-7503-7507

3) Priyadarsini P., Bharthvajan R.,Role of emotional intelligence training programme in reducing the stress of the nurses,2014,International Journal of Applied Engineering Research,V-9,I-22,P-7411-7421

4) Kerinab Beenu G., Bharthvajan R.,Empirical analysis on the cosmetic buying behavior of young women in South India,2014,International Journal of Applied Engineering Research,V-9,I-22,P-7361-7366

5) Balakrishnan P., Bharthvajan R.,Whistling in the wind,2014,International Journal of Applied Engineering Research,V-9,I-22,P-7586-7593

6) Krishnan B., Peter M.,Health hazards of Indian Bpo employee-an alarming issue,2014,International Journal of Applied Engineering Research,V-9,I-22,P-7336-7341

7) Kerinab Beenu G.H., Peter M.,Role of insurance in economic development,2014,International Journal of Applied Engineering Research,V-9,I-22,P-7532-7539

8) Balakrishnan P., Peter M., Priyadarsini P.,Efficiency of safety measures for wellbeing of employees in manufacturing industry,2014,International Journal of Applied Engineering Research,V-9,I-22,P-7376-7382

9) Anbarasi M., Praveen Kumar S.,Online sales promotions of herbal products and its effectiveness towards tanisha.com,2019,Indian Journal of Public Health Research and Development,V-10,I-1,P-195-200

10) Anbarasi M., Praveen Kumar S.,Various online marketing and promotions strategies to improve the validation towards the organic products in the pharmaceutical sectors,2019,Indian Journal of Public Health Research and Development, V-10,I-1,P-263-269

11) Loganathan R., Praveen Kumar S.,Grievance handling a key factor for solving issues of employees in an organization,2014,International Journal of Applied Engineering Research,V-9,I-22,P-7483-7491

12) Loganathan R., Praveen Kumar S.,Study on preference of private label brands in super and Hypermarkets,2014,International Journal of Applied Engineering Research,V-9,I-22,P-7327-7335

13) Smitha M., Praveen Kumar S.,Understanding stress and its managementamong the nurses in Chennai city,2014,International Journal of Applied Engineering Research,V-9,I-22,P-7560-7565

14) Kerinab Beenu G.H., Praveen Kumar S.,A study on the investment behavior of Chennai investors in mutual fund schemes,2014,International Journal of Applied Engineering Research,V-9,I-22,P-7520-7525

15) Loganathan R., Praveen Kumar S.,Retention strategies key for organizational productivity,2014,International Journal of Applied Engineering Research,V-9,I-22,P-7443-7447

16) Pavithra J., Ganesan M., Brindha G.,State wise analysis of microfinance sector in India,2016,International Journal of Pharmacy and Technology,V-8,I-4,P-23417-23432

17) Pavithra J., Ganesan M.,A comparative study on microfinance in India and abroad,2016,International Journal of Applied Business and Economic Research,V-14,I-8,P-5471-5476

18) Pavithra J., Ganesan M.,A study on awareness and impact of micro-financial schemes,2016,International Journal of Applied Business and Economic Research,V-14,I-8,P-5449-5460

19) Senthilmurugan P., Pavithra J.,Consumer preference towards organised retailing with reference to Big Bazaar,2014,International Journal of Applied Engineering Research,V-9,I-22,P-7469-7475

20) Senthilmurugan P., Pavithra J.,Implication of social media marketing in growing healthcare industry,2014,International Journal of Applied Engineering Research,V-9,I-22,P-7448-7456

21) Loganathan R., Pavithra J.,Consumer perception towards private label brand over other brands in super markets and
hypermarkets,2014,International Journal of Applied Engineering Research,V-9,I-22,P-7355-7360

22) Kerinab Beenu G., Pavithra J.,Tradeâ€"off between liquidity and profitability in logistics industry,2014,International Journal of Applied Engineering Research,V-9,I-22,P-7398-7401

23) Kerinab Beenu G., Pavithra J.,A study on the prospective consumerâ€ ${ }^{\mathrm{TM}_{\mathrm{S}}}$ perception towards utility cars in Chennai city,2014,International Journal of Applied Engineering Research,V-9,I-22,P-7526-7531

24) Pavithra J., Dilli Babu P., Ambuli T.V.,A study on budgetary control at Maruti Service Masters, Chennai,2014,International Journal of Applied Business and Economic Research,V-12,I-2,P-151-161

25) Pavithra J., Dilli Babu P., Ambuli T.V.,A study on customer satisfaction of retro Garments Pvt Ltd, Chennai,2014,International Journal of Applied Business and Economic Research,V-12,I-2,P-381-391

26) Kerinab Beenu G.H., Pavithra J., Senthilmurugan P.,A study on the influence of promotional activities for TATA ARIA among consumers in Chennai,2014,International Journal of Applied Engineering Research,V-9,I-22,P-7572-7578

27) Vijayaragavan S.P.,An investigative expert that's general FBG sensors,International Journal of Mechanical Engineering and Technology,V-8,I-8,PP-1500-1505,Y-2017

28) Vijayaragavan S.P.,Equalization routing protocol for $\mathrm{Wi}-\mathrm{Fi}$ sensor strategy,International Journal of Mechanical Engineering and Technology,V-8,I-8,PP-1662-1666,Y-2017

29) Karthik B., Kiran Kumar T.V.U., Vijayaragavan P., Bharath Kumaran E.,Design of a digital PLL using 0.35 $\hat{\mathrm{I}}^{1} / 4 \mathrm{~m}$ CMOS technology,Middle East Journal of Scientific Research,V-18,I-12,PP-1803-1806,Y-2013

30) Kanniga E., Selvaramarathnam K., Sundararajan M.,Kandigital bike operating system,Middle - East Journal of Scientific Research,V

31) Jasmin M., Vigneshwaran T., Beulah Hemalatha S.,Design of power aware on chip embedded memory based FSM encoding in FPGA,International Journal of Applied Engineering Research,V-10,I-2,PP-4487-4496,Y-2015

32) Jasmin M.,Optimization techniques for low power VLSI circuits,Middle East Journal of Scientific Research,V-20,I-9,PP-1082-1087,Y-2014

33) Jasmin M., Vigneswaran T.,Fuzzy controller for error control of on - Chip communication,2017 International Conference on Algorithms, Methodology, Models and Applications in Emerging Technologies, ICAMMAET 2017,V-2017-January,I-,PP-1-5,Y-2017

\section{AUTHORS PROFILE}

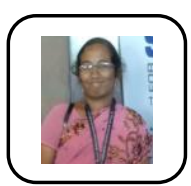

Ms. J Pavithra Assistant Professor, Department of MBA, Bharath Institute of Higher Education and Research, Chennai, India.

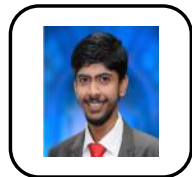

Gowtham ashirvad kumar Assistant Professor, Department of MBA, Bharath Institute of Higher Education and Research, Chennai, India.

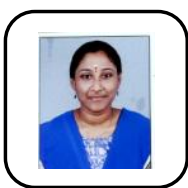

Sangeetha. M Sytudent, Department of MBA Bharath Institute of Higher Education and Research, Chennai, India. 